Article

\title{
Mitigating Climate Change in the Cultural Built Heritage Sector
}

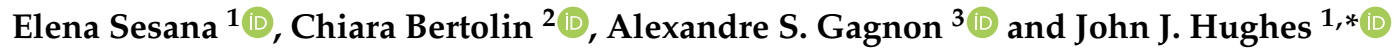 \\ 1 School of Computing, Engineering and Physical Sciences, University of the West of Scotland, High St, \\ Paisley PA1 2BE, UK \\ 2 Department of Architecture and Technology, Norwegian University of Science and Technology (NTNU), \\ Alfred Getz vei 3, 7491 Trondheim, Norway \\ 3 School of Natural Sciences and Psychology, Liverpool John Moores University, James Parsons Building, \\ Byrom Street, Liverpool L3 3AF, UK \\ * Correspondence: john.hughes@uws.ac.uk
}

Received: 14 May 2019; Accepted: 8 July 2019; Published: 11 July 2019

check for updates

\begin{abstract}
Climate change mitigation targets have put pressure to reduce the carbon footprint of cultural heritage buildings. Commonly adopted measures to decrease the greenhouse gas (GHG) emissions of historical buildings are targeted at improving their energy efficiency through insulating the building envelope, and upgrading their heating, cooling and lighting systems. However, there are complex issues that arise when mitigating climate change in the cultural built heritage sector. For instance, preserving the authenticity of heritage buildings, maintaining their traditional passive behaviours, and choosing adaptive solutions compatible with the characteristics of heritage materials to avoid an acceleration of decay processes. It is thus important to understand what the enablers, or the barriers, are to reduce the carbon footprint of cultural heritage buildings to meet climate change mitigation targets. This paper investigates how climate change mitigation is considered in the management and preservation of the built heritage through semi-structured interviews with cultural heritage experts from the UK, Italy and Norway. Best-practice approaches for the refurbishment of historical buildings with the aim of decreasing their energy consumption are presented, as perceived by the interviewees, as well as the identification of the enablers and barriers in mitigating climate change in the cultural built heritage sector. The findings emphasise that adapting the cultural built heritage to reduce GHG emissions is challenging, but possible if strong and concerted action involving research and government can be undertaken to overcome the barriers identified in this paper.
\end{abstract}

Keywords: adaptation; climate change; cultural heritage; energy efficiency; historical buildings; mitigation; refurbishment; sustainability

\section{Introduction}

By ratifying the Kyoto Protocol, the European Union (EU) committed to reducing its emissions of greenhouse gases (GHGs). Such a commitment was further reinforced by the 2015 Paris Agreement in which the EU agreed to a 40\% reduction in GHG emissions by 2030 [1]. This can be accomplished, in part, by improving the energy efficiency of buildings as they are responsible for $40 \%$ of the total energy consumption in Europe [2,3]. However, a large percentage of the European building stock is composed of historical buildings, with $35 \%$ of them over 50 years old and $75 \%$ inefficient in their use of energy $[2,4]$. The potential contribution of the cultural built heritage sector to GHG emission reduction targets is therefore significant and requires action.

The United Nations Educational, Scientific and Cultural Organization (UNESCO), the International Centre for the Study of the Preservation and Restoration of Cultural Property (ICCROM) and the 
International Council on Monuments and Sites (ICOMOS) have pledged for the development of mitigation strategies applied to cultural heritage. This is particularly relevant to Europe where a large percentage of the heritage properties inscribed in the UNESCO World Heritage List are located [5]. They also encourage managers to reduce GHG emissions at site level, especially within the World Heritage network [6]. Strategies to mitigate climate change in the built heritage sector include the implementation of energy efficiency measures, for instance, decreasing the use of energy for lighting, heating, cooling and ventilation, or reducing the energy used for transporting building materials. Other measures which can contribute to mitigation efforts include waste reduction, reusing and recycling materials, using sustainable materials and processes and decreasing water use $[7,8]$. The carbon footprint of the cultural built heritage can also be reduced through energy efficiency planning and interventions to decrease emissions within its own management [9].

The cultural built heritage sector can therefore significantly contribute to climate change mitigation. The aim of this paper is to understand how climate change mitigation is currently considered in the management and preservation of the cultural built heritage in Europe. Specifically, the objectives are to determine the perspectives of experts in cultural heritage preservation on the enablers - and the barriers - to mitigate climate change within their sector, and to identify best-practice approaches for the refurbishment of historical buildings with the aim of decreasing their energy consumption.

\section{Mitigating Climate Change in the Cultural Built Heritage Sector}

There is an increasing body of research on climate change mitigation in the built heritage sector, with most studies focusing on reducing the energy used in heritage buildings through retrofitting efforts, i.e., improvements in the thermal performance of the building envelope, and upgrading the heating, ventilation and air conditioning systems. Less research has been accomplished on the use of traditional passive measures in historical buildings as strategies to reduce energy consumption, and on the use of the Life Cycle Assessment (LCA) methodology for the selection of materials requiring less energy to produce, and thus emitting less $\mathrm{CO}_{2}$. There is also limited research on energy saving measures induced by changes in user behaviours, and on the challenges associated with improving the energy efficiency of heritage buildings in relation to the impact of the refurbishment on their historical value.

Several studies investigated possible retrofitting solutions for historical buildings to reduce their energy consumption. The proposed measures include improved thermal insulation of floors and roofs, external wall insulation through the use of highly insulating plaster [10], the installation of more efficient (and draught-proofing) windows, the improvement of heating, cooling, ventilation and lighting systems (e.g. installation of light emitting diodes [LEDs]), the installation of photovoltaic tiles, and even the elimination of rising damp [11-13]. Hence, previous studies have mainly presented examples of retrofitting of historical buildings that have been successful in decreasing the building energy consumption.

Improvements in the insulation of the building envelope is a major theme in climate change mitigation. There are several options and evidence for their varying effectiveness, including recently advanced options. For example, Berardi [14] investigated the properties of aerogel systems with plasters, concrete tiles/panels and fibre blankets, emphasizing that these materials have great thermal performance, but they are too expensive to be used for a sustainable economic return. Also, Zhou et al. [15] investigated the performance of internally insulated walls with aerogel-based high insulating plaster and renders such as lime mortar and mineral plaster, indicating that internal retrofitting using such materials can alter the hygrothermal performance of walls and, for this reason, recommended caution in their use. Novel but more traditional methods of insulation can also be used, e.g., Nardi et al. [16] investigated the upgrading of the internal vertical envelope using insulating panels made of hemp fibre, which resulted in increased thermal performance. There are, nonetheless, possible disadvantages resulting from these building alterations, such as an increase in decay caused 
by changes in hygrothermal performance and vapour movement when new materials are introduced to increase thermal performance.

Another area of attention is the improvement of the heating, cooling, ventilation and lighting systems e.g., [17], and the cogeneration of heat and power using renewable energy sources to reduce the buildings' operational energy requirements. These can include heat pumps as heating and cooling systems, which use outdoor air, underground water e.g., $[18,19]$ and heat stored in the ground e.g., [20-22], demand-controlled ventilation and trigeneration technologies [18], efficient lighting systems [23] and 'hybrid' energy systems [24]. Unlike other research, Lo Basso et al. [24] considered the heritage values as a key factor to take into consideration when proposing changes to the heating and power system of historical buildings, notably in the use of photovoltaics, solar hybrid collectors, and heat pumps as solutions to effectively reduce their energy consumption. This is because there is a risk of incompatibility, as the use photovoltaic systems, for example, can affect the aesthetic value of a historical building. These examples, amongst others, paint a complex picture; it can be difficult to identify a solution due to the subjectivity of different aspects to take into consideration when designing refurbishment measures, such as values and money.

Traditional passive measures adopted in historical buildings use renewable energy sources, notably wind and solar, for heating, cooling and ventilation. Such measures include the design of patios and courtyards to improve building ventilation [25], the use of natural ventilation [26,27], double windows [28], and coloured reflecting mortars and tiles [29,30]. On the one hand, these measures can effectively maximize the intrinsic characteristics and behaviours of historical buildings, for example by using natural ventilation in heavyweight buildings for night pre-cooling in warm climates [26]. On the other hand, these approaches should consider aspects such as heritage value preservation and the energy embodied in the materials of the building, i.e., the energy required for their extraction, manufacturing, transportation, and during construction. For instance, Rosso et al. [29] demonstrated that the energy demand for cooling a building was decreased by using newly developed coloured reflecting mortars and tiles. However, the aesthetic impact of applying these new mortars should be evaluated against the potential loss of heritage values and the energy embodied in the original mortars and tiles. One could argue that if the historical tiles are not damaged, there is no reason to replace them, as their replacement will result in GHG emissions and a loss of heritage value. Effectively, the energy embodied in historical buildings is rarely considered in energy-retrofit strategies [31,32]. The adaptive reuse of heritage building materials can reduce GHG emission; nonetheless, historical buildings still need to be upgraded to be energy-efficient over their full life cycles [32]. Some assessments have compared the energy embodied in historical materials with materials that are more recent. However, such comparison should not be done on its own and needs to consider the historical and cultural value of the ancient materials. The adaptive reuse of historical buildings allow for preserving both the energy embodied in the material and the heritage values of the building [33].

Also, Litti et al. [34] investigated the replacement of historical windows with new ones as an additional measure to improve thermal insulation. The findings highlight that replacing windows does not necessarily allow for the largest energy savings over their full life-cycles, while their maintenance may result in comparable or more considerable savings [34]. In fact, the LCA methodology can be used to select solutions or materials using less energy and thus emitting less $\mathrm{CO}_{2}$, however, the application of the LCA methodology is still in its infancy in the cultural heritage sector [35,36]. As a result of this gap in knowledge, Bertolin and Loli [37] developed a decision-support tool integrating a LCA approach within the framework of building conservation principles, nonetheless, they highlighted the need for further work in this direction given the complexity of this issue.

There are not only material aspects to consider when retrofitting historical buildings. Users' behaviour has an important role to play in mitigating climate change, as it determines the preference and choice for room temperature and ventilation, for instance [38], and can help target specific groups in carbon reduction strategies. Many studies highlighted the high energy saving potential derived from changes in user behaviour [39-43], which they estimated to range from 62 to $86 \%$ [40]. Human 
behaviour, however, can lead to a rebound effect in energy usage. Hens et al., [44] showed an example of such a rebound effect with the average indoor temperature of houses increasing after improving insulation. The increasingly energy-intensive way of life should also be considered when designing energy-efficiency policies and strategies by promoting lifestyles compatible with carbon reduction [45]. Occupants' behaviours in their use of energy can be approximated using variables such as type of dwelling or the Heating, Ventilation and Air Conditioning (HVAC) system they use, and thus help at targeting carbon reduction strategies to specific groups. Guerra Santin et al. [46] found that occupants living in non-detached dwellings or in houses where thermostats are installed consume less energy, for instance. This shows that more engagement with behavioural research is needed to identify opportunities for reducing GHG emissions [47].

Yarrow [48] investigated the perspectives of building professionals, planners and home owners in relation to not only the issue of climate change mitigation when refurbishing historical buildings, but also on the challenges involved in relation to the impact of energy efficiency improvements on the historical significance of heritage buildings. On the one hand, there is pressure to preserve the authenticity of the historic built environment, but, on the other hand, there is pressure to mitigate climate change. Considering the above options, it is clear that many mitigation choices involve physical alteration of heritage assets. This raises the question as to whether the mitigation solutions proposed in the literature are compatible with the heritage values and also with the traditional characteristics and behaviour of historical materials and structures. This is a complex issue and there are contrasting examples in the literature. For instance, Ascione et al. [49] developed a methodology to select measures to retrofit a historical building according to energy, environmental and economic indicators. Using that methodology, one of the solutions identified was the replacement of the historical windows with new double glazed ones, a solution that was proposed without considering the values of the heritage building. As an example of best practice, De Santoli et al. [50] focused on reducing the heat load of a historical building and, to deal with this issue, their proposed solution consisted of an air exchange system integrated with the existing architectural elements of the building, such as chimneys and fireplaces. By converting them to a new role, the solution remained compatible with the heritage values, and minimised changes to the building fabric. Webb [43] further stressed that energy retrofitting of historical buildings can be an opportunity to help preserve them for future generations. There is an inherent complexity in balancing the drivers and constraints of mitigation-related energy retrofitting of historical buildings [48]. There is a desire to improve internal comfort and to reduce operating costs, while the need to preserve heritage values can constrain mitigation actions; for example, Cornaro et al. [10] discounted the potential for interior wall insulation due to the presence of frescoes.

Overall, the literature on approaches to reduce GHG emissions in historical buildings focuses on presenting case studies on measures to improve the thermal performance of historical buildings, e.g., building envelope insulation and upgrading of heating and cooling systems. This is in addition to generic advice on reducing the environmental footprint of historical buildings through retrofitting, renewable energy generation on site, offsetting carbon emissions, managing waste and using water more efficiently, both from a technical point of view e.g., [8,51,52] and for informing buildings' owners and the public see [53-55]. This review highlights the paucity of studies on the challenges to overcome in the cultural built heritage sector to mitigate climate change. A broader picture is needed to inform and support decision making on the priorities to consider when promoting climate change mitigation in the cultural built heritage sector. A number of questions remain insufficiently addressed in the literature, notably, how do experts involved in the preservation of the cultural built heritage consider climate change mitigation? What are the enablers for implementing mitigation strategies, and what are the barriers to overcome? Answering those questions is essential for the development of mitigation measures and for the identification of future research directions. To date, most studies have used quantitative methods, except for Yarrow [48] who followed a qualitative approach. The current study uses a qualitative methodology involving interviews with experts, and the above literature review was conducted to provide background information for the interpretation of the interviewees' responses. 
To the author's knowledge, this is the first paper that identifies enabling and constraining factors as well as examples of best practice in mitigating climate change in the built heritage sector as a result of consultations with experts.

\section{Methodology}

The methodology used in this study consisted of qualitative semi-structured interviews with experts in the preservation and management of cultural heritage. In total, 45 interviews were conducted in the UK, Italy and Norway; three European countries with different climates and heritage typologies. The selection of case study sites in those three countries allowed for triangulation of information. These sites were also selected as they form part of a larger project led by the first author with research on vulnerability and adaptation to climate change risks reported elsewhere $[56,57]$. The number of interviews was based on the principle of saturation in qualitative research, i.e., when it became evident that there was redundancy in the interviewees' answers and no new theme emerged, no additional interviews were conducted. The interviewees were academics and researchers working in different universities and research centres, including experts involved in EU-funded projects focusing on climate change and cultural heritage (42\%); practitioners working in organizations and institutions with a focus on the preservation of cultural heritage (27\%), and managers, coordinators and professionals involved with UNESCO World Heritage Sites (WHS) (31\%). Eighty percent of interviewees have more than 10 years of experience working on preserving cultural heritage and there were more males than women interviewees (Table 1).

Table 1. Characteristics of the interviewees: type of organization where they work, number of years working in the cultural heritage sector and gender $(n=45)$.

\begin{tabular}{ccc}
\hline Type of Organization. & $\begin{array}{c}\text { Number of Year Working in the } \\
\text { Cultural Heritage Sector }\end{array}$ & Gender \\
\hline Universities and research centres $=42 \%$ & $1-9$ years $=20 \%$ & Male $=58 \%$ \\
\hline Governmental institutions $=27 \%$ & $10-19$ years $=30 \%$ & Female $=42 \%$ \\
\hline Heritage sites $=31 \%$ & $20-29$ years $=30 \%$ & \\
\hline & $30-39$ years $=18 \%$ & \\
\hline & $>40$ years $=2 \%$ & \\
\hline
\end{tabular}

The interviewees were from diverse backgrounds and specializations, including anthropologists, archaeologists, architects, conservation scientists, geologists, biologists, managers and coordinators of heritage sites, sustainability officers and urban planners. The structure of the interviews was prepared in advance, but during the interviews the order and number of questions varied according to the interviewees' expertise and answers (i.e., the interviews were semi-structured). Introductory questions on the professional background of the interviewees were followed by a list of questions focusing on themes related to climate change mitigation in the cultural heritage sector: GHG emission reductions at heritage sites, improvement in the energy performance of historical buildings, sustainability of materials, and methods used during conservation practices. Ethical approval for this research was obtained through the University of the West of Scotland procedure. The interviews were audio recorded and then transcribed, analysed and coded using the NVivo software (Version 11, QSR International (UK) Limited, Daresbury, Cheshire, UK). The interviews were conducted in English in the UK and Norway and in Italian in Italy. The Italian interviews were not translated during the coding process but some quotes were translated for the purpose of displaying samples of interview quotations in Tables 2-4. 
Table 2. Selected quotations in relation to the factors enabling climate change mitigation in the cultural built heritage sector.

\begin{tabular}{|c|c|}
\hline Themes & Quotes \\
\hline \multirow{6}{*}{$\begin{array}{l}\text { Economic } \\
\text { factors }\end{array}$} & "(Give) incentives (to) (...) people to make compatible (...) interventions." (Academic) \\
\hline & $\begin{array}{l}\text { "Incentives, (...) funding programs (...) could help people to (...) (do) things that otherwise they cannot do." } \\
\text { (Heritage site manager) }\end{array}$ \\
\hline & $\begin{array}{l}\text { "The state or municipality should provide incentives (and give funding) (...) (also) for non-listed buildings. (...) } \\
\text { The gap between economic, cultural, historical and social value should be bridged." (Academic) }\end{array}$ \\
\hline & $\begin{array}{l}\text { "When things cost more to do in the right way we have to have the willingness to pay more." (Heritage site } \\
\text { coordinator) }\end{array}$ \\
\hline & "Recovering money (...) through energy saving." (Academic) \\
\hline & $\begin{array}{l}\text { "It is better to give work to people that live in the place and that can do maintenance, instead of bringing low } \\
\text { quality windows from abroad." (Academic) }\end{array}$ \\
\hline \multirow{6}{*}{$\begin{array}{l}\text { Legislation and } \\
\text { regulations }\end{array}$} & "(It) would be really helpful, particularly with tenements, if there was more legislation." (Heritage site manager) \\
\hline & "There has to be work on the development of guidelines in collaboration with the municipalities." (Academic) \\
\hline & $\begin{array}{l}\text { "You have to get it written in management plans. (...) We need (...) tools, action and activities to help them." } \\
\text { (Academic) }\end{array}$ \\
\hline & $\begin{array}{l}\text { "(Regarding) making the buildings more energy efficient, (enforce) policy requirements when it is a public } \\
\text { building." (Academic) }\end{array}$ \\
\hline & "To report the carbon usage of the building ( ... ) on how the building is energy efficient." (Academic) \\
\hline & $\begin{array}{l}\text { Normally buildings consume more energy compared (with) how they were designed. Post-evaluation needs to be } \\
\text { performed and needs a regulatory structure." (Academic) }\end{array}$ \\
\hline \multirow{7}{*}{$\begin{array}{l}\text { Sustainable } \\
\text { refurbishment } \\
\text { strategies }\end{array}$} & "Focus on reuse and adaptability. (Avoid) building waste." (Academic) \\
\hline & $\begin{array}{l}\text { "For the stonework (...) they sourced stone from a bridge that has been dismantled." (Member of governmental } \\
\text { institution) }\end{array}$ \\
\hline & "Use natural resources and materials." (Heritage site manager) \\
\hline & $\begin{array}{l}\text { "We rely on natural materials. We (...) promote the broader advantages in sustainability of the historic } \\
\text { environment in terms of social-economic sustainability (...) local jobs, skills. (...) Instead of getting something } \\
\text { (from abroad), we (engaged) a local firm. (...) Sustainable in terms of materials, (...) low carbon in terms of the } \\
\text { local economy." (Member of governmental institution) }\end{array}$ \\
\hline & $\begin{array}{l}\text { "(Use) sustainable (products). Instead of mineral wool, there are wood-based products. ( ... ) Traditional } \\
\text { materials: wood, stone..." (Academic) }\end{array}$ \\
\hline & $\begin{array}{l}\text { "Every construction phase should consider the LCA (...) (this) is little applied to cultural heritage. Its } \\
\text { conservation (...) should be done with low emissions." (Academic) }\end{array}$ \\
\hline & $\begin{array}{l}\text { "(Historical buildings) will not be passive houses nor be A+++. We need to understand what we mean by } \\
\text { sustainability. If we change everything, losing the material and the energy used to produce it, we will have a better } \\
\text { building in terms of thermal performance, but we lost much more grey energy. We need to evaluate the } \\
\text { sustainability through } 360 \text { degrees." (Academic) }\end{array}$ \\
\hline \multirow{3}{*}{$\begin{array}{l}\text { Sustainable } \\
\text { transportation } \\
\text { strategies }\end{array}$} & "(Pedestrianisation) of historical city centres is a positive thing." (Academic) \\
\hline & $\begin{array}{l}\text { "Sundays without cars helps in sensitising (the issue). ( . . . ) To go in the city centre with the bike ... " } \\
\text { (Researcher) }\end{array}$ \\
\hline & $\begin{array}{l}\text { "Promote appropriate transport. ( ... ) people do not actually think to cycle instead of taking a bus." } \\
\text { (Sustainability officer) }\end{array}$ \\
\hline \multirow{6}{*}{$\begin{array}{l}\text { Change in user } \\
\text { behaviour }\end{array}$} & $\begin{array}{l}\text { "Encourage people to conserve energy, save resources, recycle and reuse. (...) Those things have to become the } \\
\text { norm, rather that something special." (Heritage site manager) }\end{array}$ \\
\hline & $\begin{array}{l}\text { "We achieved } 30 \% \text { of reduction in carbon emission over } 4 \text { years based on (...) fabric interventions (and) change } \\
\text { in behaviour." (Member of governmental institution) }\end{array}$ \\
\hline & "Wear another jumper instead of putting in double glazing." (Heritage site manager) \\
\hline & $\begin{array}{l}\text { "Run climate change and mitigation energy awareness. ( ... ) Reduce the demand." (Member of governmental } \\
\text { institution) }\end{array}$ \\
\hline & "Work with owners and motivate them." (Academic) \\
\hline & "Engage the citizenship." (Researcher) \\
\hline \multirow{2}{*}{ Knowledge } & "It has very much to do with knowledge (... ) (and) information" (Academic) \\
\hline & "Sharing the knowledge (... ) contributing to research" (Heritage site manager) \\
\hline
\end{tabular}


Table 2. Cont

\begin{tabular}{ll}
\hline Themes & Quotes \\
\hline $\begin{array}{l}\text { Energy } \\
\text { compensation } \\
\text { strategies }\end{array}$ & $\begin{array}{l}\text { "Face (the problem) at district or city level. (...) (Historical) buildings can be put in a grid of energy distribution } \\
\text { at distel (and receive) the energy surplus" (Academic) }\end{array}$ \\
\cline { 2 - 2 } & $\begin{array}{l}\text { "The concept of trade-off. (...) New design with thermal inefficiency in some parts but with improved efficiency in } \\
\text { others." (Academic) }\end{array}$ \\
\hline
\end{tabular}

Table 3. Barriers in mitigating climate change in the cultural built heritage sector.

\begin{tabular}{ll}
\hline Theme & Quote \\
\hline \multirow{3}{*}{$\begin{array}{l}\text { Economic } \\
\text { factors }\end{array}$} & \begin{tabular}{l} 
"There is very little incentive for certain building owners." (Academic) \\
\cline { 2 - 3 }
\end{tabular} \\
\cline { 2 - 2 } & "Sometimes we are asking people to do things in a more expensive way." (Architect) \\
& "Guidelines were created but (...) they will remain only suggestions if there is no political will to be stricter." \\
& "Provide regulation to force (energy efficiency upgrade) of properties." (Academic)
\end{tabular}

Lack of

"The regulation plan says that existing buildings can be refurbished (...) but the character, materials and colour regulation should be kept. (...) People should keep the material, (...) (make) repairs, (...) (but people) change them (...) interpreting the unclear text in regulation." (Academic)

"Governments (...) are interested in devolution of regulation to local level (... ) (including) cultural heritage protection or listed buildings consent (... ). But, do the (local authorities) have the capacity, (interest, and) (...) knowledge? And, when (... ) you ask who is looking at cultural heritage, (...) they would say, "oh, we could not afford it". (...) There is the need to have more written advice. (Member of governmental institution)

"The older the building is and the more value the heritage has the harder it is. (...) If the building is mid-20 th century (...) (you can) get it in a high standard. But (...) (with) a castle there is a limit on how far you can go." (Academic)

"Insulating the outside of historical buildings in terms of authenticity and integrity (...) it is unthinkable. There is a balance with the cultural significance of the elements." (Academic)

"I wouldn't like to (...) see solar panels all over beautiful old buildings. (They can) (...) be sited somewhere (else)." (Heritage site manager)

Value

"You never want to lose the original fabric, like crown glass or (...) timber sashes to put double glazing. (...) You never get character back again because you can't make crown glass anymore. (...) With traditional stone buildings (...) you don't want to alter the external fabric (...) (and) lose the (internal) original cornices and plaster work." (Heritage site manager)

"They prefer to build new low emission buildings and demolish existing historical buildings. (...) If you look only at the environmental issues and not at the cultural (value) you are making wrong choices." (Academic)

"Lack of information and education of the community on (...) heritage (value)" (Academic)

"(When) refurbishing without taking into consideration the authenticity of the materials (...) (historic elements) are replaced (...) with totally different detailing." (Academic)

"Local materials should be more sustainable than (foreign), (...) (but) emission from shipping are not accounted in any assessment (and) it (results) more (sustainable) to buy from foreign countries." (Sustainability officer)

"Modern materials can travel all the world (...) (before to) come back to you." (Academic)

"Little stock is produced. (...) (few) quarries (still) exist (. . ). You have to replace with stone (that) very often (...) comes from (abroad)."(Academic)

Material procurement and "Resources from abroad (... ) means that you are getting alien materials, there isn't a correct geological match." (Heritage site manager)

sustainability certification

"Local material (...) correspond better to (building) typologies and expression. (... ) You (should) pay more for (...) (transportation) emissions."(Academic)

"If you are replacing (elements) (...) are you calculating those carbon costs? (...) What about the destruction of what (...) has last seven hundred years? (...) It is a waste of money (...) (and) energy." (Heritage site manager)

"This country calculates $\mathrm{CO}_{2}$ only within the borders (...). So, (foreign) stone (... ) has much smaller carbon footprint legally compared from (local) stone." (Academic)

"(Sustainability assessments) are very good for new construction, ( . . ) (but tricky with) refurbishment. (...) EPC (and) (...) building standards are really good for (new) or just refurbished buildings, but (there is) nothing on historic values. (Sustainability officer)

"There are problems on how the (EPC) rating presumes the performance (... ) we do not have data on the actual performance of the buildings." (Academic) 
Table 3. Cont

\begin{tabular}{|c|c|}
\hline Theme & Quote \\
\hline \multirow{4}{*}{ User behaviour } & $\begin{array}{l}\text { "You make (a building) more energy efficient and theoretically you reduce the carbon emissions, then you find that } \\
\text { they are using it in a way that it is not proper. Carbon emissions are made also from the users." (Academic) }\end{array}$ \\
\hline & $\begin{array}{l}\text { "There is a cultural resistance to lighting from windows. ( ... ) Electric artificial systems used when not } \\
\text { necessary it is a big issue. People still think that lighting is low in consumption, but it is not." (Academic) }\end{array}$ \\
\hline & $\begin{array}{l}\text { "Everybody wears t-shirts (in offices). ( ... ) We do not try to save the energy as hard as we could." (Heritage } \\
\text { site manager) }\end{array}$ \\
\hline & $\begin{array}{l}\text { "The use-phase is important. (...) (heat pumps) were introduced to use less electricity, but now people have } 25 \\
\text { degrees (indoor) (...). I do not know if they actually decreased the energy at the end. It is a rebound effect. You can } \\
\text { have zones in your house (...), night and day regulation, (...) educate people (to) (...) put on a jumper in winter ( } \\
\text {.. ). (But) they just want to stay with their t-shirt. (...) People do not know why they should (do) it." } \\
\text { (Academic) }\end{array}$ \\
\hline \multirow{6}{*}{$\begin{array}{l}\text { Lack of } \\
\text { knowledge }\end{array}$} & $\begin{array}{l}\text { "If we (use) (...) a modern material, it can cause increase of decay with formation of mould, for example. We need } \\
\text { tests to know the consequences of their application." (Academic) }\end{array}$ \\
\hline & $\begin{array}{l}\text { "We need to understand which are the characteristics and the behaviours (of ancient buildings) and work with } \\
\text { them." (Academic) }\end{array}$ \\
\hline & $\begin{array}{l}\text { "We need skills of preservation of (old) materials. (...) (and) use the same methods (...) used when they were } \\
\text { built, not look only at today's methods (...) and guidelines for energy efficiency." (Heritage site coordinator) }\end{array}$ \\
\hline & $\begin{array}{l}\text { "The sash and case windows were designed for having air conditioning. (...) A lot of historical buildings have this } \\
\text { inherent ability. (...) There is the need to understand the capacity of these buildings to cope with the external } \\
\text { environment and to maintain (comfort)." (Member of governmental institution) }\end{array}$ \\
\hline & $\begin{array}{l}\text { "If people's opinion is that new is always better, they are going to replace (elements). (...) If you promote to keep } \\
\text { them (...) that would help. But the (market is) (...) advertising for new windows. Heritage managers are not } \\
\text { considered experts in energy efficiency." (Academic) }\end{array}$ \\
\hline & $\begin{array}{l}\text { "People do what they want (...) entrepreneurs put new insulation (...) (which cause) problems with air tightness } \\
\text { compromising your building." (Academic) }\end{array}$ \\
\hline \multirow{3}{*}{$\begin{array}{l}\text { Loss of } \\
\text { traditional skills }\end{array}$} & $\begin{array}{l}\text { "Traditional skills are going to be lost. If I have a technician that just mount PVC windows instead of a craftsman } \\
\text { (...) able to build a wooden window or to fix an ancient door, we are losing something." (Academic) }\end{array}$ \\
\hline & $\begin{array}{l}\text { "Other important resources are the technicians. We do not have enough people who know traditional skills" } \\
\text { (Academic) }\end{array}$ \\
\hline & $\begin{array}{l}\text { "Some craftsman know about (historical buildings behaviour) but a lot (...) use the same techniques for new } \\
\text { buildings in the old ones; (... ) the building industry does not take this into consideration." (Academic) }\end{array}$ \\
\hline \multirow{6}{*}{$\begin{array}{l}\text { Incompatible } \\
\text { solutions }\end{array}$} & "Changing the behaviour of the building will cause inside a series of problems." (Academic) \\
\hline & $\begin{array}{l}\text { "We need to be careful in adding insulation (...) (in) buildings. You can upset their balance, (...) blocking natural } \\
\text { ventilation and causing cold bridges." (Heritage site manager) }\end{array}$ \\
\hline & $\begin{array}{l}\text { "You want to (...) increase energy efficiency, but people are not worried about humidity and condensation causing } \\
\text { deterioration in the fabric."(Member of governmental institution) }\end{array}$ \\
\hline & $\begin{array}{l}\text { "(In) wooden buildings (...) there would be vapour condensation somewhere, it is very important to (...) ventilate } \\
\text { (...). Damp barriers (...) prevent the house to breathe (....) (and) cause decay. People do not understand (or know } \\
\text { about building physics)." (Academic) }\end{array}$ \\
\hline & $\begin{array}{l}\text { "Some levels of comfort are not sustainable for some heritage buildings. (...) Heating and cooling inside churches } \\
\text { can increase decay." (Academic) }\end{array}$ \\
\hline & $\begin{array}{l}\text { "The energy strategy (in refurbishments can be) contradictory. (...) (A refurbished building) had an overheating } \\
\text { problem (...) because of the (...) IT equipment. (...) They (internally) insulated a wall with a huge thermal mass, } \\
\text { (that) now cannot absorb the heat from computers, and they have to activate air conditioning." (Member of } \\
\text { governmental institution) }\end{array}$ \\
\hline \multirow{2}{*}{ Diversity } & $\begin{array}{l}\text { "You have to take each building or set of buildings. When were they built? How? (...)For what? What use can be } \\
\text { made of it now?" (Academic) }\end{array}$ \\
\hline & $\begin{array}{l}\text { "That would be a question to raise in each building and the answer would be different from building to building. It } \\
\text { is hard to generalize." (Academic) }\end{array}$ \\
\hline
\end{tabular}


Table 4. Best-practice examples of cultural heritage refurbishment measures to mitigate climate change, as proposed by the interviewees.

\begin{tabular}{|c|c|}
\hline Theme & Quote \\
\hline \multirow{5}{*}{ Insulation } & "Internal insulation, heat pump, soil insulation and roof insulation, improving the windows..." \\
\hline & $\begin{array}{l}\text { "Maintain the wooden windows. (...) Putting insulation in the roofs, putting double glazing in the windows, } \\
\text { using heat pumps..." }\end{array}$ \\
\hline & "Insulation of floors, ceilings and roofs..." \\
\hline & $\begin{array}{l}\text { "Put secondary glazing on historic windows ( ... ) removable secondary glazing with magnets ( ... ) double } \\
\text { glazing in winter and in summer you can take it off." }\end{array}$ \\
\hline & $\begin{array}{l}\text { "Put insulation under the floor, in the ground floor, towards the basement, in the roof. (...) Make the building } \\
\text { more airtight. Put secondary glazing or double glazing in historic windows without replacing them. (...) Make } \\
\text { zones. Halls in the entrance. (... Insulation in certain walls (...) that are re-built. }\end{array}$ \\
\hline \multirow{3}{*}{$\begin{array}{l}\text { Insulation and } \\
\text { ventilation }\end{array}$} & $\begin{array}{l}\text { "Installing secondary glazing in windows to reduce the heat loss, improving the insulation in walls, floors and } \\
\text { ceilings. Reducing drafts. (...) Maintain the ventilation in historical buildings (...) in roofs. (...) Closing } \\
\text { curtains and having shutters." }\end{array}$ \\
\hline & $\begin{array}{l}\text { "Have shutters, heavy curtains, and secondary glazing. (...) Make sure that there is good ventilation. Add } \\
\text { insulation where appropriate." }\end{array}$ \\
\hline & $\begin{array}{l}\text { "Insulate in the inside (only if adequate) (...) provide the right ventilation (...) make sure that you have got no } \\
\text { condensation (...) new curtains or tapestry on the walls. (...) Using the blinds, using curtains (...). Insulate } \\
\text { under floor." }\end{array}$ \\
\hline \multirow{2}{*}{ Ventilation } & $\begin{array}{l}\text { "Mixed mode or hybrid ventilation system, in some cases natural ventilation supported by mechanical ventilation. } \\
\text { (... ) Mechanical devices to improve the natural ventilation of buildings in a controlled way." }\end{array}$ \\
\hline & $\begin{array}{l}\text { "Passive ventilation. (Avoid) air conditioning. ( ...) A lot of buildings ( ...) had passive ventilation, (...) like } \\
\text { chimneys and louvers }(. . .) \text { (that) provide thermal comfort with less energy." }\end{array}$ \\
\hline Lighting & "Good light management process." \\
\hline $\begin{array}{l}\text { Lighting and } \\
\text { insulation }\end{array}$ & $\begin{array}{l}\text { "Changing light bulbs, repairing windows, secondary glazing, new lamping, loft insulation, cavity wall } \\
\text { insulation." }\end{array}$ \\
\hline Heating & "Do not heat the building but heat the people." \\
\hline $\begin{array}{l}\text { Heating, } \\
\text { lighting, } \\
\text { monitoring. }\end{array}$ & $\begin{array}{l}\text { "Install LED bulbs. (...) Change the windows putting up films for the summer shading, upgrade the roof. Improve } \\
\text { the cooling and lighting systems. (...) Monitoring the environmental conditions all year." }\end{array}$ \\
\hline
\end{tabular}

The interviews transcripts were coded using the categories: "enablers", "barriers" and "best practice". Subsequent to coding, the transcripts were used to search for patterns in the data. This search for patterns in the coded interview transcript led to the identification of themes representing the factors enabling and those impeding climate change mitigation in the built heritage sector was then determined by analysing the coded interview transcripts and are displayed in Figure 1.

Examples of quotes from the interviewees in relation to each of the identified themes are shown in Tables 2-4 to explain the selection of specific themes and the categorisation of the information provided by the interviewees. These representative quotes were carefully selected and shortened to reduce the word count without compromising their meaning. The use of direct quotations allows the reader to have a better understanding of the respondents' perceptions about climate change mitigation. The results do not present commonalities or differences amongst the interviewees, as the purpose of this paper is to highlight the factors enabling or constraining climate change mitigation in the cultural heritage sector, including examples of best practice for its implementation, as well as to inform decision-makers and to identify research needs. Figure 2 summarises the steps involved in this qualitative methodology: 


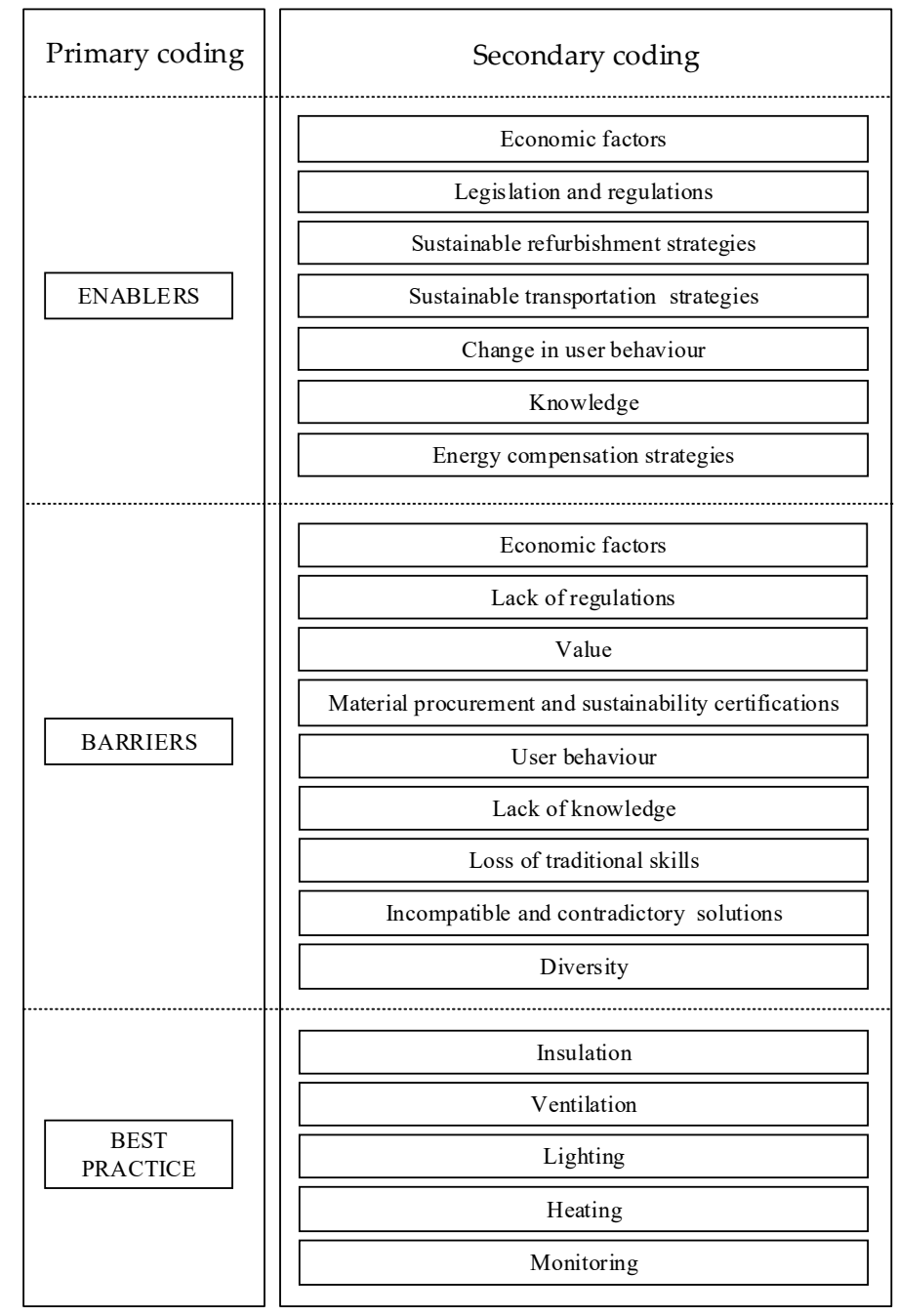

Figure 1. List of primary and secondary coding.

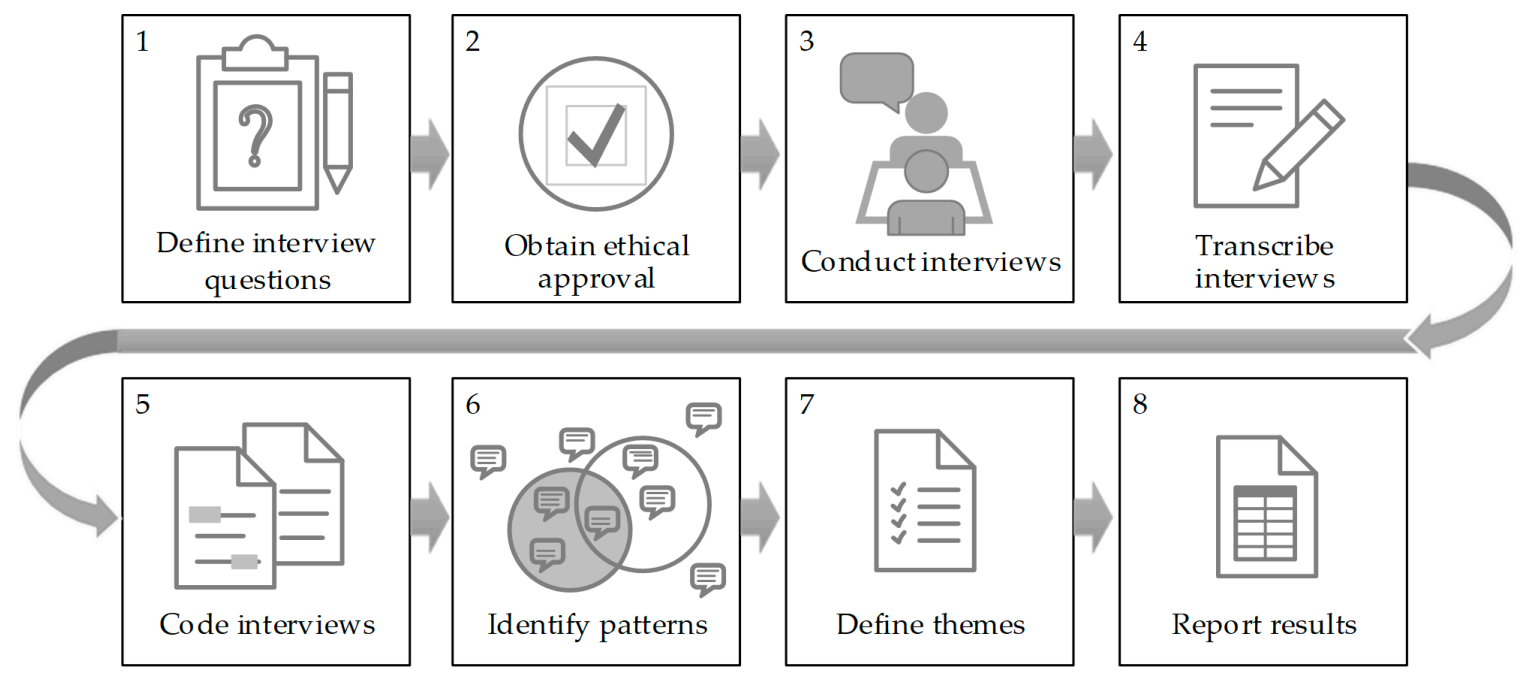

Figure 2. The qualitative methodology used in the current research.

\section{Results and Discussion}

The investigation first examined the interviewees' perceptions to identify the factors that enable and those that act as barriers to climate change mitigation in the cultural built heritage sector. During the 
interviews, the participants addressed issues such as reducing carbon emissions and the transition to a low carbon economy, improvements in the energy performance of historical buildings, the preservation of heritage values, the sustainability of materials and methods used for refurbishing and restoring heritage assets.

\subsection{Enablers of Climate Change Mitigation in the Cultural Built Heritage Sector}

The interviewees were positive about adapting the cultural built heritage to mitigate climate change and identified a number of factors that enable this. These factors were grouped into six themes: 'economic factors', 'legislation and regulations', 'sustainable refurbishment strategies', 'sustainable transport strategies', 'user behaviour', 'knowledge' and 'energy compensation strategies' (see Table 2). Figure 3 shows the number of interviewees mentioning each of the identified enablers. For example, 13 interviewees, i.e., the $29 \%$ of the total number of interviewees, mentioned 'economic factors' as an enabling factor to climate change mitigation in the cultural heritage sector.

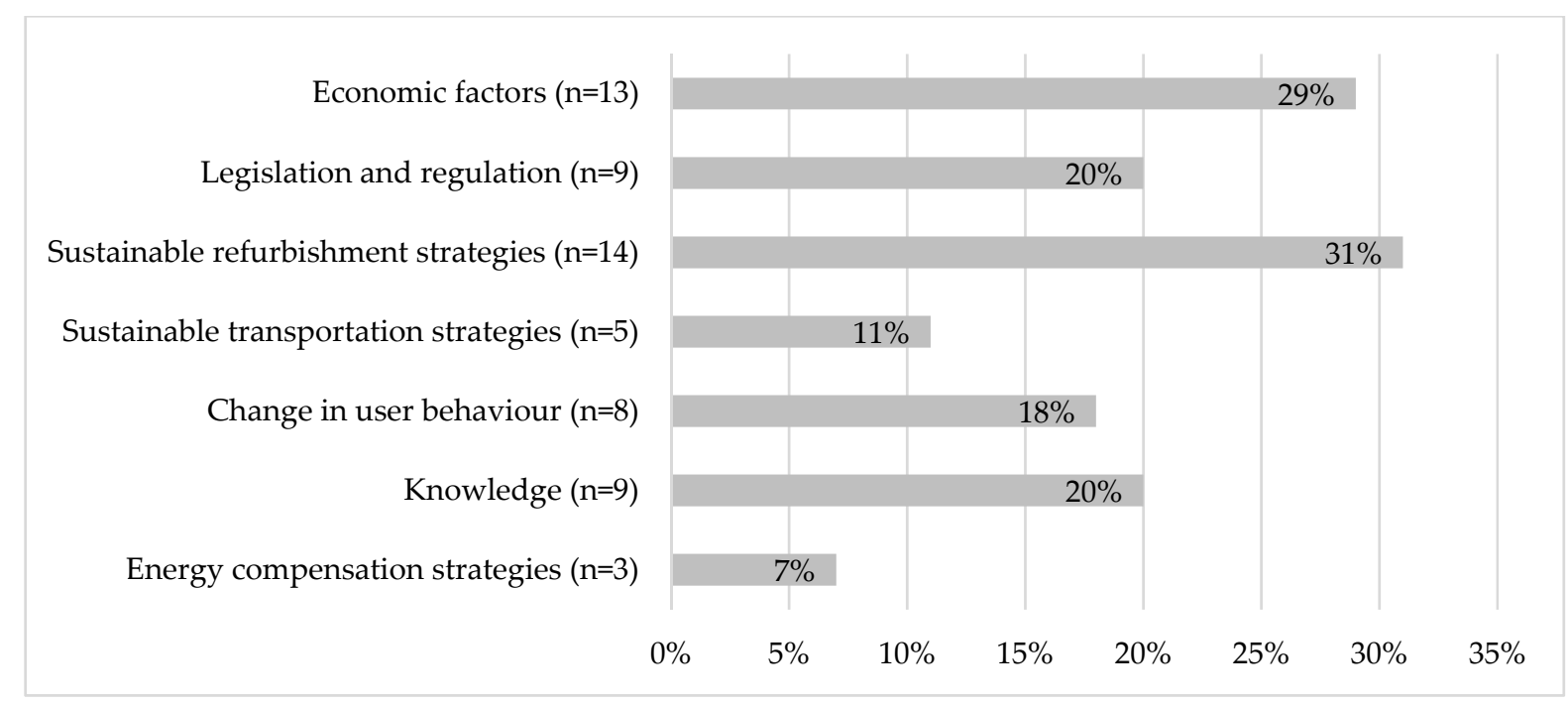

Figure 3. Percentage (and number) of interviewees mentioning each of the different enablers of climate change mitigation. ( $n$ is the number of interviewees mentioning the enabler).

\subsubsection{Economic Factors}

The interviewees perceived as important the economic factors that enable the implementation of strategies to mitigate climate change. Government incentives was the most mentioned measure by the interviewees. Such incentives are used to encourage people to make interventions compatible with the heritage assets instead of choosing market-forced solutions that are often not compatible with the heritage values. The interviewees found that the wider (non-expert) public can be reluctant to restore traditional windows due to the high costs involved and the belief that the restored windows will be less energy efficient than alternative new double-glazed windows. However, as mentioned above, the results of previous research concluded that window replacement is not necessarily a better energy saving measure. Considering the energy used in the life cycle of the windows, restoring, instead of replacing the windows, can be a better choice [34]; in addition, the energy cost related to the transport of the new elements is avoided. The interviewees also emphasised that restoration efforts compatible with the heritage building should be encouraged with the help of incentives so that people are willing to pay more for them. This is particularly the case when the money invested in the refurbishment efforts can be recovered in the long-term from the energy saved subsequent to the refurbishment efforts. The interviewees suggested restoring and maintaining the original historical materials as an opportunity for improving local economic sustainability against the importation of foreign materials and for maintaining as well as increasing traditional expertise locally. 


\subsubsection{Legislation and Regulations}

According to the interviewees, having more legislation, regulations and guidelines would facilitate climate change mitigation in the cultural heritage sector. New regulations were requested not only at the international, national and regional level, but also in municipalities and at cultural heritage sites. In fact, it was even suggested to include climate change mitigation in site management plans, but also to increase policy requirements for mitigation actions in public buildings. A specific request by the interviewees was the need to improve the regulatory structure behind carbon usage reports and post-performance evaluations in order to better monitor the energy consumed in refurbished buildings during the use-phase and to compare it with the energy usage that was predicted prior the refurbishment. Consistent with this information gathered from the interviewees, there is agreement in the literature that ambitious policies can significantly reduce the energy use in buildings [58], and that for successful mitigation in the cultural heritage sector, policy actions at both the regional and local levels are needed [7,59]. In addition, Yarrow [48] highlighted a potential conflict between legislation promoting preservation of cultural heritage and that requiring a reduction of energy consumption in buildings, hence the difficulty of applying general policies to historical buildings.

\subsubsection{Sustainable Refurbishment Strategies}

The interviewees suggested a number of actions aimed at improving sustainability and thus at reducing the GHGs emitted by the cultural built heritage sector. Examples of sustainable actions in relation to the refurbishment of historical buildings include the selection of environmentally friendly and natural materials, especially if originating from local sources, recycling and reusing materials, avoiding the use of harmful chemical substances and minimising the generation of building waste. However, sometimes it is difficult to understand whether one way to refurbish a historical building is more sustainable than another is. For this reason, the sustainability of the materials and refurbishment actions should be assessed using the LCA methodology prior to the implementation of the refurbishment efforts. This would provide a better understanding of the energy and $\mathrm{CO}_{2}$ emissions associated with a specific intervention. Such an approach, however, should also consider the embodied energy in the historical materials that are proposed to be replaced. The latter is consistent with Webb [43] who mentioned the lack of consideration of the embodied energy of historical buildings during retrofitting. Hence, further work is required on the evaluation of the sustainability of the materials and methods used during refurbishment in the built heritage sector, as the LCA approach has been applied mostly on new construction rather than on historical buildings [48], a gap in knowledge which Bertolin and Loli [37] also had previously highlighted. In addition, when applying the LCA approach to the heritage sector, the historical and cultural values need to be considered and added as a parameter in the evaluation of the solutions to be adopted. These values are often neglected and priority is often given to new technologies and to materials targeted at energy reduction [37], without considering the sustainability of the cultural built heritage sector in a holistic way as mentioned by an interview in the following quote: "We need to evaluate (...) sustainability through 360 degrees." (Table 1).

\subsubsection{Sustainable Transportation Strategies}

The interviewees also emphasised the need to improve environmental sustainability at cultural heritage sites by reducing $\mathrm{CO}_{2}$ emissions through the promotion of sustainable transport to and from the sites as well as within the sites. This can be accomplished, for example, by promoting cycling and public transportation, as well as by closing historic town and city centres to domestic vehicles. The latter can also contribute to decreasing air pollution and thus improving air quality, as well as reducing the associated decay on monuments and the facades of historical buildings [60]. 


\subsubsection{Change in User Behaviour}

User behaviour has a significant impact on the effectiveness of mitigation measures adopted on historical buildings. The interviewees recommended to encourage users, e.g., occupants and visitors, to behave in a more sustainable way and mentioned the need to raise awareness through engagement to ensure that mitigation is effective. Users should be educated in energy and water saving measures, reusing and recycling materials, and decreasing their waste and emissions. This can start through simple things such as wearing a jumper inside the building in the winter and thus reducing the use of heating, instead of wearing only a t-shirt, for instance. Berg et al. [38] emphasised the importance and potential of user-driven energy efficiency measures in historical buildings and that user behaviour should always be taken into account, as the occupants play a central role in the day-to-day management of the building. The Intergovernmental Panel on Climate Change (IPCC) [58] further highlighted that in developed countries, behavioural change could decrease energy use by up to $20 \%$ in the short-term and by up to $50 \%$ by the middle of the $21^{\text {st }}$ century.

\subsubsection{Knowledge}

Some interviewees suggested more knowledge through research and dissemination as a factor enabling mitigation in the cultural heritage sector. This is consistent with the literature, which emphasises the role of new knowledge and skills to develop new sustainable strategies for heritage conservation to face climate change uncertainty [51].

\subsubsection{Energy Compensation Strategies}

Some interviewees suggested the application of energy compensation schemes. This is where parts of a system that are inefficient in their use of energy can benefit from the energy surplus produced by the efficient parts. In relation to cultural heritage, this can be done at different scales: city district and building. In the first case, different buildings in the same district can share energy. For instance, the energy needed for historical buildings can be supplied by the surplus energy produced by new energy efficient buildings or from off-site renewable sources of energy. GHG emission reductions through such a trading allowance is a cost-saving measure that was proposed by Cassar [51]. In the second case, one interviewee mentioned the possibility to meet the energy requirements for parts of a historical building where no refurbishment is allowed with the energy saved by improving the thermal performance of other parts of the buildings where modifications are permitted.

\subsection{Barriers to Climate Change Mitigation In The Cultural Built Heritage Sector}

In addition to the factors found to enable climate change mitigation in the cultural built heritage sector, the interviewees also identified a number of barriers. These barriers were grouped into nine themes: 'economic factors', 'lack of regulation', 'value', 'material procurement and sustainability certification', 'user behaviour', 'loss of traditional skills', 'lack of knowledge', 'incompatible solutions' and 'diversity'. Figure 4 shows the number of interviewees mentioning each of the identified enablers as well as their percentages. Eleven interviewees, i.e., the $24 \%$ of the total number of interviewees, mentioned 'economic factors' as a barrier to climate change mitigation in cultural heritage sector. Table 3 provides examples of quotes from the interviewees in relation to each enabling factor. 


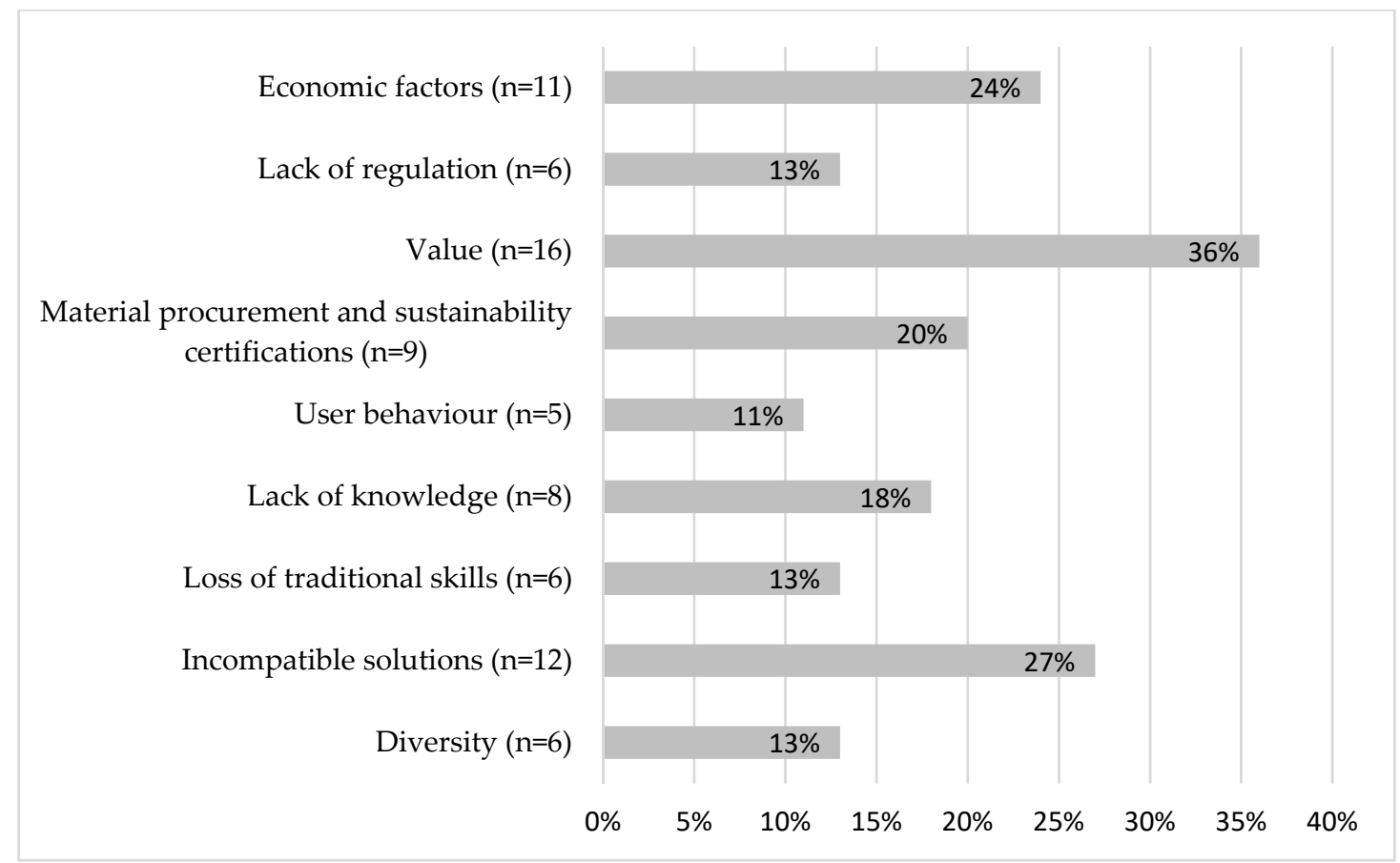

Figure 4. Percentage of interviewees mentioning each barrier ( $n$ is the number of interviewees mentioning the barrier).

\subsubsection{Economic Factors}

The interviewees perceived economic factors as an important barrier to climate change mitigation in the cultural built heritage sector as restoring historical buildings is expensive. Thus, financial resources can help with conservation efforts when they are limited or not available. The lack of money to restore cultural heritage can also have negative consequences on the inherent historical, cultural and social values embedded in heritage sites. For example, an interviewee stated: "There is an economic aspect that prevails over the social, historical and cultural value." (Table 2). The adoption of cheaper solutions and in particular the loss of original material can influence the historical and cultural values of the site, as well as weaken the identity of a place. The economics of conservation is therefore an important criterion to consider when retrofitting historical buildings [43].

\subsubsection{Lack of Regulation}

A significant barrier perceived by the interviewees is the lack of regulation when adapting cultural heritage to mitigate climate change. The interviewees highlighted that stronger regulations are required to force the owners of heritage assets to adapt properly. An interviewee mentioned the example of a UNESCO WHS, where detailed guidelines were carefully designed and provided to the local community, but people did not follow them due to lack of enforcement. An interviewee from another WHS mentioned misinterpretation of the regulations as an issue, where the components of historical buildings were replaced with similar substitutes, albeit made of different materials characteristics, varying in shape and colour from the original components. Such substitution can decrease the authenticity of a heritage site. There are parallel examples between the information provided by the interviewees and case study examples reported in the literature. Yarrow [48], for instance, reported the concern of a conservation officer regarding a retrofitting where the building owners substituted the historical components for new ones claiming that they 'looked the same'. Devolution of the regulations to the local level was also mentioned as a problem by one interviewee, because, in some cases, a lack of financial and human resources put cultural heritage preservation in second place. The lack of protocols 
and guidelines to help heritage managers adapt cultural heritage assets to climate change was also highlighted by Sabbioni et al. [8].

\subsubsection{Value}

Some interviewees perceived preserving the values of cultural heritage as a barrier to climate change mitigation, because it limits the refurbishment options to make historical buildings more energy efficient. This is because the measures adopted when retrofitting heritage assets can affect the heritage value, notably when historical elements are removed and replaced. Preserving the values of cultural heritage on the one hand and the implementation of measures to reduce the carbon footprint of heritage assets on the other hand should always be carefully balanced in any refurbishment project and, in this respect, buildings of diverse ages and listing category should be considered differently. The interviewees highlighted that preserving heritage value, authenticity and integrity should be prioritized when considering adaptation measures and strategies, as once the historical materials are removed and destroyed they will be lost forever. For this reason, the interviewees suggested alternatives to refurbishing buildings of high heritage value, such as integrating them as part of district energy networks, as described in Section 4.1.6, with the curbed $\mathrm{CO}_{2}$ emissions from retrofitted buildings used to offset the higher energy used in historical buildings.

One interviewee further added that it would be beneficial to have examples of public building refurbishment that preserve the value, integrity and authenticity of the heritage as models for others to follow: "Long-term adaptation planning has to be done first in public buildings to be an example for the private." (Table 3). Another interviewee representing a government organisation recommended selecting adaptation measures that would not conflict with the heritage value: "Where we had (...) a potential for losing the values, we just do not go there. We would rather do something else." An example of the latter is restoring historical wooden windows by inserting a secondary glazing with magnets, which can be removed during the warmer season, rather than replacing the windows with new ones. When refurbishing historical buildings, evidence is needed to justify retrofitting changes that influence the value, integrity and authenticity of the building. If restoration impacts on the value of those building, their historical meaning could be lost [51]. Historic Environment Scotland (HES), a governmental institution in charge of preserving cultural heritage in Scotland advises on the unrealistic expectation that historical buildings can reach energy efficiency levels similar to new constructions but also advises for adaptive solutions that preserve the value, identity and significance of those assets to the community [61]. Furthermore, it should be emphasized that if the refurbishment of historical buildings can be seen as a threat to the heritage values, retrofitting can also constitute an opportunity to protect buildings, for example to heritage buildings in disuse or to those with minimal maintenance carried out [43].

\subsubsection{Material Procurement and Sustainability Certification}

The interviewees identified material procurement used during refurbishment of cultural heritage buildings as a barrier to climate change mitigation, as well as weaknesses in building sustainability certifications. With globalization, building materials are increasingly imported from other countries and, during the production process, they often travel from various locations around the world before reaching the construction site. The more a material travels, the more GHG emissions are derived from its transportation. However, the interviewees highlighted that in some cases, energy calculations and sustainability certifications do not consider the energy associated with transportation out of the country where the building is located. This can put foreign building materials at an advantage with regard to costs and certification, and this can influence the lack of locally sourced material during the refurbishment of historical buildings. The interviewees emphasized that the use of foreign materials not only increases GHG emissions, but may also not have the same characteristics as the original materials. There is also a lack of consideration of the energy embodied in the historical materials in energy evaluations. In fact, it was stated that historical buildings are not considered in performance 
qualification and building standards and that energy evaluation software are not accurate in calculating the energy used by historical buildings.

The interviewees also reported a lack of consideration of the physical behaviour of heritage buildings and of the vapour permeability of historical material and an inaccuracy of Energy Performance Certificates (EPC) that make assumptions about energy use but do not reflect the actual performance of historical buildings. Incomplete Environmental Product Declarations (EPD) can also contribute to this issue [62], and, consistent with this, Cassar [51] stressed that some sustainability certification tools do not use a holistic approach; they are based on relative energy targets and they exclude social and economic sustainability aspects. In addition, Webb [43] emphasised the lack of consideration of embodied energy during the retrofitting of historical buildings, stressing the need for improved simulation tools and software to reduce the gap between simulations data and real building performance.

\subsubsection{User Behaviour}

User behaviour is considered a barrier to climate change mitigation because certain attitudes can minimise or even nullify the refurbishment efforts aimed at decreasing the use of energy by the building. The interviewees identified resistance to change and to the adoption of sustainable behaviours, for example, leaving the lights on during the day when there is high luminosity from the window, wearing light clothes in the winter and turning the thermostat up to a level beyond comfort level, to name a few. An interviewee also mentioned the rebound effect, which is a decrease in the expected energy savings from a specific building alteration because of behavioural change leading to an increase in energy consumption. For instance, in buildings were measures were introduced to use less electricity by installing heat pumps, people further increased their energy consumption by setting room temperature to a higher level on their thermostat. Sabbioni et al. [8] even proposed a change on a regulatory level to induce a modification in user behaviour.

\subsubsection{Lack of Knowledge}

The interviewees identified a lack in knowledge as a barrier to mitigate climate change in the built heritage sector. More research testing the use of modern materials during the refurbishment of historical buildings and on the traditional behaviours and characteristics of historical building is needed. Some interviewees also identified the need for more knowledge transfer to users on the topic of climate change mitigation in the field of cultural heritage in a way to make them more aware and capable of making choices compatible with the traditional behaviours and values of historical buildings.

\subsubsection{Loss of Traditional Skills}

Another significant barrier identified by the interviewees is the progressive loss of traditional skills and techniques. Given the common incompatibility of modern solutions with historical buildings and materials, this loss can threaten heritage preservation. The need to pass on knowledge and skills to the next generation of heritage professionals, and the importance of teaching traditional skills and techniques, and to understand how they relate to modern construction materials is emphasised in the literature, as well as methods on how to develop suitable conservation techniques appropriate with the nature of older buildings [51,63].

\subsubsection{Incompatible Solutions}

When refurbishing historical buildings, the adoption of solutions that are not compatible with the behaviour of historical materials can accelerate their degradation. For instance, the interstitial condensation between layers made of different materials. The traditional behaviour of the historical buildings, their thermal-balance, the natural ventilation of their indoor environments, and the ability of some historical materials to allow vapour movement are characteristics that must be taken in consideration during a refurbishment project. More research is needed on the evaluation of market-based solutions, which are usually designed for new structures but that are also applied to 
historical buildings. Historical buildings have more sophisticated bioclimatic properties than modern constructions, and new materials that are incompatible with the physical behaviour of the historical ones can lead to an increase in decay. Retrofitting measures can alter the moisture balance of historical buildings, affecting, for example, their breathability, leading to an increase in the deterioration of historic materials $[43,48]$. Those buildings are designed to have controlled thermal comfort based on the natural unconditioned climate, environmental and site conditions rather than using machine-driven systems. The development of adaptation strategies should therefore consider the balance between decay reduction and energy consumption improvement of historical buildings [64,65].

\subsubsection{Diversity}

Some interviewees mentioned that historical buildings are too diversified for adaptation solutions to be generalised and that adaptation has to be considered on a case-by-case basis. The question remains as to whether it is possible to generalize adaptation options to decrease the energy consumption of historical buildings or if each individual cultural heritage asset is too specific. More research is needed on specific classifications, or typologies, of heritage buildings to understand which possible adaptation solution can be proposed by comparing adaptation measures used in similar situations.

\subsection{Best Practice Examples}

The last part of the investigation focused on the identification of best-practice examples in mitigating climate change, as expressed by the interviewees. Examples of best practices include refurbishment measures to increase the energy efficiency of historical buildings in relation to upgrading the insulation, ventilation, lighting and heating, as well as the monitoring of climatic conditions (Table 4). The majority of these measures are consistent with the solutions proposed in the literature and raised in Section 2 of this paper.

\subsubsection{Insulation}

The interviewees suggested insulating floors, ceilings, roofs and walls, and to reduce the loss of heat through windows by adding secondary glazing and using curtains, shutters and blinds. Examples of insulation systems used in literature are shown in Section 2 of the current paper e.g., [14-16].

\subsubsection{Ventilation}

The interviewees emphasised the need for ventilation in historical buildings to avoid condensation, which can be done by using mixed mode or hybrid ventilation systems, with mechanical devices improving natural ventilation of buildings in a controlled way, or by passive ventilation using traditional systems such as wind chimneys and louvers. Consistent with this, the literature stresses the importance of systems to control the relative humidity and the ventilation of the indoor environment of cultural heritage buildings to decrease energy consumption while also reducing the risk of degradation [17], and on the potential of chimneys for providing ventilation in traditional buildings [53].

\subsubsection{Lighting, Heating and Monitoring}

The interviewees also suggested improving lighting and heating systems while monitoring climatic conditions throughout the year. The literature presented in Section 2 backs these recommendations.

\section{Conclusions}

Mitigating climate change by reducing GHG emissions is now urgent to prevent future-and reduce current-danger to cultural heritage resources. This needs to be accomplished, in part, by reducing the energy used by cultural built heritage assets, notably through improvements in their energy efficiency. Organizations such as UNESCO, ICOMOS, ICCROM, IPCC and the European Commission promote actions to cut GHG emissions in the cultural built heritage sector. This paper 
analysed the perceptions of cultural heritage experts on the issue of adapting the cultural built heritage to mitigate climate change. Specifically, it reports on the factors enabling and those acting as barriers to mitigate climate change, as perceived by the managers of heritage sites and experts working on the preservation of cultural heritage in universities, research centres and governmental institutions.

A common view amongst the interviewees was that climate change mitigation in the heritage sector is necessary but challenging. Most research accomplished to date investigated measures to mitigate climate change by reducing the energy consumption of cultural heritage buildings, but there is limited research on the identification of the challenges to overcome in this regard. This paper provides a better understanding of what needs to be provided and prioritized for the mitigation of climate change in the cultural built heritage sector to take place. In summary, this study identified the following barriers constraining climate change mitigation in the field of cultural heritage: economic factors, lack of regulation, heritage values as it can limit the type and scope of refurbishment, inadequacies in material procurement and sustainability certifications, inefficient use of energy due to building occupants' behaviour, lack of knowledge, loss of traditional skills, the adoption of solutions incompatible with the assets and hence causing further damage, diversity of heritage resources and hence the difficulty to identify solutions that are fit for all. The factors enabling climate change mitigation that could help to overcome some of those identified barriers include economic resources and incentives, legislation and regulations, sustainable refurbishment strategies, sustainable transportation strategies, change in user behaviour, knowledge, and energy compensation strategies. Figure 5 provides a graphical summary of the factors enabling and constraining climate change mitigation in the field of cultural heritage.

This research emphasised that mitigating climate change in the cultural built heritage sector is a complex issue and requires a holistic approach for the identification of sustainable strategies to reduce GHG emissions. In this regard, ambiguities still remain on the consideration of heritage values and the energy embodied in historical materials, as well as the potential of traditional passive measures when adapting heritage buildings to mitigate climate change. This study improves our qualitative understanding of the key themes raised by stakeholders and can be used as a basis for further research seeking to quantify the effectiveness of best practice in climate change mitigation in the cultural heritage sector. Specifically, further research should be developed on adaptation strategies that consider the balance between reduction of decay and improving the energy consumption of historical buildings [64]. More research should also be conducted on the use of traditional solutions for improving energy efficiency, and on the compatibility (or lack) of new technologies and materials with the historical ones. Historical buildings work differently from modern buildings. Further research is required on the re-use of traditional passive measures such as wind chimneys, greenhouses, passive ventilation and heating, to name a few, and thus avoiding carbon intensive energy consumption, as well as on the promotion of sustainable natural resources, e.g., wind and sunlight. This could be done by understanding the level of energy efficiency achievable by different types of heritage (e.g. ancient castles and monuments versus non-ancient historical assets) in relation to their values, integrity and authenticity.

Monitoring before and after retrofitting and/or refurbishment works should be encouraged to estimate properly the energy consumption and the energy payback period from the use of renewable sources post intervention. This includes the need to rectify the current energy certification process, which does not consider the energy used to transport materials when historical materials are replaced by new ones in their calculations; the need for LCA evaluations before refurbishing historical buildings to understand the impact of the proposed solutions on the environment; and the need to promote the use of natural materials to avoid toxic chemicals.

A decrease in energy consumption also needs to be promoted through changes in user behaviour (e.g. wearing appropriate clothes and heating less, reducing the heating of rooms when not used, use more natural illumination and less electricity), which can be implemented with the use of information and communication technology (ICT). More knowledge needs to be disseminated and collaboration between different countries and at different levels should be encouraged, from the governmental 
to the end user. Including increasing awareness and cooperation between heritage organizations, governmental institutions, research centres and academia.

\begin{tabular}{|c|c|}
\hline \multicolumn{2}{|c|}{ MITIGATING CLIMATE CHANGE IN THE CULTURAL BUILT HERITAGE SECTOR } \\
\hline ENABLERS & BARRIERS \\
\hline Economic factors & Economic factors \\
\hline \multirow{2}{*}{$\begin{array}{ll}\text { - } & \text { Incentives } \\
\text { - } & \text { Economic return } \\
\text { - } & \text { Local economic sustainability } \\
\text { - } & \text { W illingness to pay for compatible } \\
& \text { work } \\
\end{array}$} & $\begin{array}{ll}\text { - } & \text { Few incentives } \\
\text { - } & \text { Costly solutions } \\
\text { - O verriding economic value }\end{array}$ \\
\hline & Lack of regulations \\
\hline Legislation and regulations & \multirow{2}{*}{$\begin{array}{ll}\text { - } & \text { Lack of regulations or obligations } \\
\text { - } & \text { Devolution of regulations } \\
\text { - } & \text { Unclear regulations } \\
\end{array}$} \\
\hline \multirow{3}{*}{$\begin{array}{l}\text { - } \quad \text { More legislation and guidelines } \\
\text { - } \quad \text { Post-performance evaluations and } \\
\text { report on carbon usage }\end{array}$} & \\
\hline & Value \\
\hline & \multirow{3}{*}{$\begin{array}{l}\text { - Value preservation as a barrier to } \\
\text { mitigation and mitigation as a barrier } \\
\text { to value preservation } \\
\text { Loss of heritage resources and } \\
\text { materials }\end{array}$} \\
\hline Sustainable refurbishment strategies & \\
\hline \multirow{4}{*}{$\begin{array}{l}\text { - Use natural and locally sourced } \\
\text { materials } \\
\text { - } \quad \text { Reuse materials } \\
\text { - } \quad \text { Conduct Life Cycle Assessments } \\
\text { holistic way } \\
\end{array}$} & \\
\hline & \multirow{2}{*}{$\begin{array}{l}\text { Material procurement and sustainability } \\
\text { certifications }\end{array}$} \\
\hline & \\
\hline & \multirow{3}{*}{$\begin{array}{ll}\text { - } & \text { Lack of local material } \\
\text { - } & \text { Energy for transport Procurement } \\
\text { strategy } \\
\text { - } \\
\text { - Embodied energy } \\
\text { - } \quad \text { Sustainability certification } \\
\end{array}$} \\
\hline Sustainable transportation strategies & \\
\hline \multirow{2}{*}{$\begin{array}{l}\text { Promote cycling, public transport } \\
\text { and pedestrianisation of historical } \\
\text { city centres }\end{array}$} & \\
\hline & User behaviour \\
\hline Change in us er behaviour & \multirow{2}{*}{$\begin{array}{ll}\text { - } & \text { Post-refurbishment wrongusage } \\
\text { - } & \text { Unrealistic energy demand } \\
\text { - } \quad \text { Electric lighting abuse } \\
\text { - W aste of energy }\end{array}$} \\
\hline \multirow{2}{*}{$\begin{array}{ll}\text { - } & \text { Save resources, recycle, reuse } \\
\text { - } & \text { Change in behaviour to reduce } \\
\text { carbon emission } \\
\text { - } & \text { Raise awareness }\end{array}$} & \\
\hline & Lack of knowledge \\
\hline Knowledge & $\begin{array}{l}\text { - Lack of knowledge on historical } \\
\text { buildings behaviour }\end{array}$ \\
\hline \multirow{2}{*}{$\begin{array}{ll}- & \text { Increase knowledge } \\
\text { - } & \text { Disseminate information } \\
\text { - } & \text { Conduct more research }\end{array}$} & Loss of traditional skills \\
\hline & $\begin{array}{l}\text { - Lack of technician with traditional } \\
\text { skills }\end{array}$ \\
\hline \multirow{4}{*}{$\begin{array}{l}\text { Energy compensation strategies } \\
\text { - } \quad \text { Energy distribution at district level } \\
\text { with historical buildings receiving } \\
\text { the energy surplus } \\
\text { - Compensating thermal or energy } \\
\text { performance of different building } \\
\text { areas }\end{array}$} & Incompatible and contradictory solutions \\
\hline & $\begin{array}{l}\text { - } \quad \text { Potential increase in damage } \\
\text { - Contradictory solutions making vain } \\
\text { the energy refurbishment efforts }\end{array}$ \\
\hline & Diversity \\
\hline & $\begin{array}{l}\text { - Difficulty in generalize solutions for } \\
\text { different building characteristics }\end{array}$ \\
\hline
\end{tabular}

Figure 5. Summary of the research findings. 
Author Contributions: Conceptualization, E.S., A.G., C.B. and J.H.; Data curation, E.S.; Formal analysis, E.S.; Funding acquisition, E.S., A.G. and J.H.; Investigation, E.S.; Methodology, E.S. and A.G.; Project administration, A.G.; Resources, J.H.; Supervision, A.G., C.B. and J.H.; Validation, C.B.; Visualization, E.S.; Writing-original draft, E.S.; Writing-review \& editing, A.G., C.B. and J.H.

Funding: The University of the West of Scotland provided a university studentship to support the doctoral studies of the first author. The Postdoctoral and Early Career Researcher Exchanges (PECRE) funding scheme of the Scottish Funding Council and awarded by the Scottish Alliance for Geoscience, Environment and Society (SAGES) supported the academic exchanges of the first author to Italy and Norway.

Acknowledgments: We thank all the interviewees for their time and information, and Historic Environment Scotland for the grey literature provided. We are also grateful to The Institute of Atmospheric Sciences and Climate, National Research Council of Italy (ISAC-CNR) in Bologna and the Norwegian University of Science and Technology (NTNU) in Trondheim where two academic exchanges were conducted, and to the Scottish Funding Council via the Scottish Alliance for Geoscience, Environment and Society (SAGES) who funded those two academic visits.

Conflicts of Interest: The authors declare no conflict of interest.

\section{References}

1. European Commission. Communication from the Commission to the European Parliament and the Council. The Road from Paris: Assessing the Implications of the Paris Agreement and Accompanying the Proposal for a Council Decision on the Signing, on Behalf of the European Union, of the Paris Agreement Adopted Under the United Nations Framework Convention on Climate Change; European Commission: Brussels, Belgium, 2016.

2. EU. Energy performance of buildings. Available online: https:/ec.europa.eu/energy/en/topics/energyefficiency/buildings (accessed on 21 August 2018).

3. European Commission. Communication from the Commission to the European Parliament, the Council, the European Economic and Social Committee, the Committee of the Regions and the European Investment Bank; European Commission: Brussels, Belgium, 2015.

4. European Union. Directive 2010/31/eu of the European Parliament and of the Council of 19 May 2010 on the Energy Performance of Buildings; European Union: Brussels, Belgium, 2010.

5. UNESCO. World Heritage in Europe Today; United Nations Educational, Scientific and Cultural Organization: Paris, France, 2016.

6. Colette, A. Climate Change and World Heritage. Report on Predicting and Managing the Impacts of Climate Change on World Heritage and Strategy to Assist States Parties to Implement Appropriate Management Responses; World heritage report; UNESCO World Heritage Centre: Paris, France, 2007; Volume 22.

7. Cassar, M. Principles of mitigation and adaptation of cultural heritage to climate change. In Climate Change and Cultural Heritage, Proceedings of the Ravello International Workshop, 14-16 May 2009 and Strasbourg European Master-Doctorate Course, Strasbourg, France, 7-11 September 2009; Lefèvre, R.-A., Sabbioni, C., Eds.; EDIPUGLIA: Bari, Italy, 2010; pp. 43-47.

8. Sabbioni, C.; Brimblecombe, P.; Cassar, M. The Atlas of Climate Change Impact on European Cultural Heritage. Scientific Analysis and Management Strategies; Anthem Press: London, UK, 2010.

9. Hambrecht, G.; Rockman, M. International approaches to climate change and cultural heritage. Am. Antiq. 2017, 82, 627-641. [CrossRef]

10. Cornaro, C.; Puggioni, V.A.; Strollo, R.M. Dynamic simulation and on-site measurements for energy retrofit of complex historic buildings: Villa mondragone case study. J. Build. Eng. 2016, 6, 17-28. [CrossRef]

11. Dalla Mora, T.; Cappelletti, F.; Peron, F.; Romagnoni, P.; Bauman, F. Retrofit of an historical building toward nzeb. Energy Procedia 2015, 78, 1359-1364. [CrossRef]

12. Franco, G.; Magrini, A.; Cartesegna, M.; Guerrini, M. Towards a systematic approach for energy refurbishment of historical buildings. The case study of albergo dei poveri in genoa, Italy. Energy Build. 2015, 95, 153-159. [CrossRef]

13. Righi, A.; Mora, T.D.; Peron, F.; Romagnoni, P. Historical buildings retrofit: The city hall of the city of motta di livenza (tv). Energy Procedia 2017, 133, 392-400. [CrossRef]

14. Berardi, U. The benefits of using aerogel-enhanced systems in building retrofits. Energy Procedia 2017, 134, 626-635. [CrossRef]

15. Zhou, X.; Carmeliet, J.; Derome, D. Influence of envelope properties on interior insulation solutions for masonry walls. Build. Environ. 2018, 135, 246-256. [CrossRef] 
16. Nardi, I.; de Rubeis, T.; Taddei, M.; Ambrosini, D.; Sfarra, S. The energy efficiency challenge for a historical building undergone to seismic and energy refurbishment. Climamed. 2017 Mediterr. Conf. Hvac Hist. Build. Retrofit Mediterr. Area 2017, 133, 231-242. [CrossRef]

17. Muñoz-González, M.C.; León-Rodríguez, L.Á.; Suárez Medina, C.R.; Teeling, C. Hygrothermal performance of worship spaces: Preservation, comfort, and energy consumption. Sustainability 2018, 10, 3838. [CrossRef]

18. Schibuola, L.; Scarpa, M.; Tambani, C. Innovative technologies for energy retrofit of historic buildings: An experimental validation. J. Cult. Herit. 2018, 30, 147-154. [CrossRef]

19. Serraino, M.; Lucchi, E. Energy efficiency, heritage conservation, and landscape integration: The case study of the san martino castle in parella (turin, italy). Energy Procedia 2017, 133, 424-434. [CrossRef]

20. Emmi, G.; Zarrella, A.; De Carli, M.; Moretto, S.; Galgaro, A.; Cultrera, M.; Di Tuccio, M.; Bernardi, A. Ground source heat pump systems in historical buildings: Two italian case studies. Energy Procedia 2017, 133, 183-194. [CrossRef]

21. Pacchiega, C.; Fausti, P. A study on the energy performance of a ground source heat pump utilized in the refurbishment of an historical building: Comparison of different design options. Energy Procedia 2017, 133, 349-357. [CrossRef]

22. Pisello, A.L.; Petrozzi, A.; Castaldo, V.L.; Cotana, F. On an innovative integrated technique for energy refurbishment of historical buildings: Thermal-energy, economic and environmental analysis of a case study. Appl. Energy 2016, 162, 1313-1322. [CrossRef]

23. Ciampi, G.; Rosato, A.; Scorpio, M.; Sibilio, S. Retrofitting solutions for energy saving in a historical building lighting system. Energy Procedia 2015, 78, 2669-2674. [CrossRef]

24. Lo Basso, G.; Rosa, F.; Astiaso Garcia, D.; Cumo, F. Hybrid systems adoption for lowering historic buildings pfec (primary fossil energy consumption)—A comparative energy analysis. Renew. Energy 2018, 117, 414-433. [CrossRef]

25. Soflaei, F.; Shokouhian, M.; Zhu, W. Socio-environmental sustainability in traditional courtyard houses of iran and china. Renew. Sustain. Energy Rev. 2017, 69, 1147-1169. [CrossRef]

26. Vitale, V.; Salerno, G. A numerical prediction of the passive cooling effects on thermal comfort for a historical building in rome. Energy Build. 2017, 157, 1-10. [CrossRef]

27. Di Turi, S.; García-Pulido, L.J.; Ruggiero, F.; Stefanizzi, P. Recovery of ancient bioclimatic strategies for energy retrofit in historical buildings: The case of the infants' tower in the alhambra. Energy Procedia 2017, 133, 300-311. [CrossRef]

28. Coillot, M.; El Mankibi, M.; Cantin, R. Heating, ventilating and cooling impacts of double windows on historic buildings in mediterranean area. Energy Procedia 2017, 133, 28-41. [CrossRef]

29. Rosso, F.; Pisello, A.L.; Castaldo, V.L.; Cotana, F.; Ferrero, M. Smart cool mortar for passive cooling of historical and existing buildings: Experimental analysis and dynamic simulation. Energy Procedia 2017, 134, 536-544. [CrossRef]

30. Becherini, F.; Lucchi, E.; Gandini, A.; Barrasa, M.C.; Troi, A.; Roberti, F.; Sachini, M.; Di Tuccio, M.C.; Arrieta, L.G.; Pockelé, L.; et al. Characterization and thermal performance evaluation of infrared reflective coatings compatible with historic buildings. Build. Environ. 2018, 134, 35-46. [CrossRef]

31. Mourão, J.; Gomes, R.; Matias, L.; Niza, S. Combining embodied and operational energy in buildings refurbishment assessment. Energy Build. 2019, 197, 34-46. [CrossRef]

32. Lidelöw, S.; Örn, T.; Luciani, A.; Rizzo, A. Energy-efficiency measures for heritage buildings: A literature review. Sustain. Cities Soc. 2019, 45, 231-242. [CrossRef]

33. De Santoli, L. Guidelines on energy efficiency of cultural heritage. Energy Build. 2015, 86, 534-540. [CrossRef]

34. Litti, G.; Audenaert, A.; Lavagna, M. Life cycle operating energy saving from windows retrofitting in heritage buildings accounting for technical performance decay. J. Build. Eng. 2018, 17, 135-153. [CrossRef]

35. Blundo, D.S.; Ferrari, A.M.; Fernández del Hoyo, A.; Riccardi, M.P.; García Muiña, F.E. Improving sustainable cultural heritage restoration work through life cycle assessment based model. J. Cult. Herit. 2018, 32, $221-231$. [CrossRef]

36. Loli, A.; Bertolin, C. Towards zero-emission refurbishment of historic buildings: A literature review. Buildings 2018, 8, 22. [CrossRef] 
37. Bertolin, C.; Loli, A. Sustainable interventions in historic buildings: A developing decision making tool. J. Cult. Herit. 2018, 34, 291-302. [CrossRef]

38. Berg, F.; Flyen, A.-C.; Godbolt, Å.L.; Broström, T. User-driven energy efficiency in historic buildings: A review. J. Cult. Herit. 2017, 28, 188-195. [CrossRef]

39. Li, Q.; Sun, X.; Chen, C.; Yang, X. Characterizing the household energy consumption in heritage nanjing tulou buildings, china: A comparative field survey study. Energy Build. 2012, 49, 317-326. [CrossRef]

40. Ben, H.; Steemers, K. Energy Retrofit and Occupant Behaviour in Protected Housing: A case Study of the Brunswick Centre in London. Energ Build. 2014, 80, 120-130. [CrossRef]

41. Winter, T. Climate change and our heritage of low carbon comfort. Int. J. Herit. Stud. 2016, 22, 382-394. [CrossRef]

42. Spigliantini, G.; Fabi, V.; Corgnati, S. Towards High Energy Performing Historical Buildings. A Methodology Focused on Operation and Users' Engagement Strategies. Energy Procedia 2017, 134, 376-385. [CrossRef]

43. Webb, A.L. Energy retrofits in historic and traditional buildings: A review of problems and methods. Renew. Sustain. Energy Rev. 2017, 77, 748-759. [CrossRef]

44. Hens, H.; Parijs, W.; Deurinck, M. Energy consumption for heating and rebound effects. Energy Build. 2010, 42, 105-110. [CrossRef]

45. Shove, E. What is wrong with energy efficiency? Build. Res. Inf. 2018, 46, 779-789. [CrossRef]

46. Guerra Santin, O.; Itard, L.; Visscher, H. The effect of occupancy and building characteristics on energy use for space and water heating in dutch residential stock. Energy Build. 2009, 41, 1223-1232. [CrossRef]

47. Stern, P.C.; Janda, K.B.; Brown, M.A.; Steg, L.; Vine, E.L.; Lutzenhiser, L. Opportunities and insights for reducing fossil fuel consumption by households and organizations. Nat. Energy 2016, 1, 16043. [CrossRef]

48. Yarrow, T. Negotiating heritage and energy conservation: An ethnography of domestic renovation. Hist. Environ. Policy Pract. 2016, 7, 340-351. [CrossRef]

49. Ascione, F.; Bianco, N.; De Masi, R.F.; de'Rossi, F.; Vanoli, G.P. Energy retrofit of an educational building in the ancient center of benevento. Feasibility study of energy savings and respect of the historical value. Energy Build. 2015, 95, 172-183. [CrossRef]

50. De Santoli, L.; Mancini, F.; Rossetti, S.; Nastasi, B. Energy and system renovation plan for galleria borghese, rome. Energy Build. 2016, 129, 549-562. [CrossRef]

51. Cassar, M. Sustainable heritage: Challenges and strategies for the twenty-first century. Apt Bull. J. Preserv. Technol. 2009, 40, 3-11.

52. EFFESUS. Energy Efficiency in European Historic Urban Districts a Practical Guidance; Fraunhofer-Center for International Management and Knowledge Economy MOEZ: Leipzig, Germany, 2016.

53. Historic Scotland. Fabric Improvements for Energy Efficiency; Historic Scotland: Edinburgh, UK, 2013.

54. Hummelt, K. Micro-Renewables in the Historic Environment; Historic Scotland: Edinburgh, UK, 2014.

55. Jenkins, M.; Curtis, R. Improving Energy Efficiency in Traditional Buildings; Historic Scotland: Edinburgh, UK, 2014.

56. Sesana, E.; Gagnon, A.; Bertolin, C.; Hughes, J. Adapting cultural heritage to climate change risks: Perspectives of cultural heritage experts in europe. Geosciences 2018, 8, 305. [CrossRef]

57. Sesana, E.; Bertolin, C.; Loli, A.; Gagnon, A.S.; Hughes, J.; Leissner, J. Increasing the Resilience of Cultural Heritage to Climate Change Through the Application of a Learning Strategy; Springer International Publishing: Cham, Switzerland, 2016; pp. 402-423.

58. IPCC. Climate Change 2014: Mitigation of Climate Change. Contribution of Working Group III to the fifth Assessment Report of the Intergovernmental Panel on Climate Change; Intergovernmental Panel on Climate Change: Cambridge, UK; New York, NY, USA, 2014.

59. VIOLET. Preserve Traditional Buildings through Energy Reduction. Available online: https://www. interregeurope.eu/violet (accessed on 29 May 2019).

60. Barca, D.; Comite, V.; Belfiore, C.M.; Bonazza, A.; La Russa, M.F.; Ruffolo, S.A.; Crisci, G.M.; Pezzino, A.; Sabbioni, C. Impact of air pollution in deterioration of carbonate building materials in italian urban environments. Appl. Geochem. 2014, 48, 122-131. [CrossRef]

61. Historic Scotland. A Climate Change Action Plan for Historic Scotland 2012-2017; Historic Scotland: Edinburgh, UK, 2012. 
62. Gelowitz, M.D.C.; McArthur, J.J. Comparison of type III environmental product declarations for construction products: Material sourcing and harmonization evaluation. J. Clean Prod. 2017, 157, 125-133. [CrossRef]

63. González Longo, C. Can Architectural Conservation Become Mainstream? In Proceedings of the 18th Scientific Symposium (ICOMOS), Florence, Italy, 10-14 November 2014.

64. Sabbioni, C.; Cassar, M.; Brimblecombe, P.; Lefevre, R.A. Vulnerability of Cultural Heritage to Climate Change; European and Mediterranean Major Hazards Agreement (EUR-OPA), Council of Europe: Strasbourg, France, 2008; pp. 1-24.

65. Cantin, R.; Burgholzer, J.; Guarracino, G.; Moujalled, B.; Tamelikecht, S.; Royet, B.G. Field assessment of thermal behaviour of historical dwellings in france. Build. Environ. 2010, 45, 473-484. [CrossRef]

(C) 2019 by the authors. Licensee MDPI, Basel, Switzerland. This article is an open access article distributed under the terms and conditions of the Creative Commons Attribution (CC BY) license (http://creativecommons.org/licenses/by/4.0/). 